\title{
Response of Different Sugar Beet Cultivars to Nitrogen Fertilizer Rates under the Arid Land Conditions
}

\author{
Ghassan H. Edrees, Fathy S. El-Nakhlawy and Saleh M. Ismail1 \\ Arid Land Agriculture Department, Faculty of Meteorology, Environment and Arid Land \\ Agriculture, King Abdulaziz University, Jeddah, Saudi Arabia \\ ghassanedrees983@gmail.com
}

\begin{abstract}
This study was conducted during 2016-2018 at the Agriculture Research Station of King Abdulaziz University at Hada Al-Sham, Saudi Arabia. The study aimed to evaluate three sugar beet cultivars (Farida, Dita and Heros) under three nitrogen fertilizer rates $(100,200$ and $300 \mathrm{~kg}$ $\mathrm{N} / \mathrm{ha}$ ). As nitrogen fertilizer rate increased root yield, yield components, sucrose (\%) and yield significantly increased in both seasons. Fresh root yield under $300 \mathrm{~kg} \mathrm{~N} / \mathrm{ha}$ was the highest in both seasons. Farida cv. was the highest in root yield (60.62 t/ha and $97.00 \mathrm{t} / \mathrm{ha}$ ) and sucrose yield (4.15 and $6.95 \mathrm{t} / \mathrm{ha})$ in both seasons, respectively.
\end{abstract}

Keywords. Cultivar, Nitrogen fertilizer, Root yield, Sucrose, Sugar beet.

\section{Introduction}

Sugar beet ((Beta vulgaris L.) is one from the main economic field crops in the world. Sugar beet is the second source for sugar production after sugar cane. It is the world's most cultivated crop after sugar cane for the production of sucrose for human consumption. Sugar beet is a crop characterized with high tolerance degree for the salinity in soil and irrigation water (Cooke and Scott, 1993). The highest sugar yield was obtained by irrigation with $75 \%$ from the total crop water requirement with $\mathrm{EC}=8 \mathrm{mmos} / \mathrm{cm}^{2}$ (Hills et al., 1983). Sucrose content increased as salinity increased (Katerji et al., 1997). Sugar beet root yield and sucrose content significantly different among the sugar beet genotypes (Refay, 2010). Nitrogen fertilizer significantly increased sucrose yield and percentage in sugar beet root (Russell et al., 1971). The highest yield was harvested on the plot fertilized with the highest $\mathrm{N}$ rate. In years with extended drought, sugar beet achieved the maximum yield in the treatment of the higher rates of nitrogen fertilizer. Nitrogen is the nutrient limiting the most sugar beet productivity (Herget, 2010). The late N application increased chlorophyll concentration in the leaves but had no significant effect on radiation use efficiency in late summer and autumn (Malnou et al., 2007). Too little $\mathrm{N}$ retards leaf growth (Milford et al., 1985) gives pale green foliage due to low chlorophyll concentration and accelerates leaf senescence (Draycott and Christenson, 2003). Too much $\mathrm{N}$ induces over-production of dark green leaves and a shift in dry matter distribution at the expense of storage root and sugar yields (Milford et al., 1988): The extra leaves seem to provide little benefit in terms of additional intercepted radiation (Scott et al., 1994). Sugar beet requires adequate $N$ to 
expand the canopy rapidly and this $\mathrm{N}$ often comes from recently applied fertilizer. However, once the canopy has been produced, the crop may increase in dry weight three fold and in $\mathrm{N}$ uptake by at least $100 \mathrm{~kg} \mathrm{ha}^{-1}$ (Last et al., 1983, Armstrong et al., 1986 and Malnou et al., 2006). Does the crop require a $\mathrm{N}$ fertilizer source for this or can $\mathrm{N}$ be absorbed in sufficient quantity and sufficiently rapidly from soil sources to maximize yield. Once a large canopy has been produced, can the soil supply enough $\mathrm{N}$ (a) to maintain canopy size so that light interception is optimized and (b) so that the foliage remains an efficient converter of light energy into dry matter and sugar (Scott and Jaggard, 1993).

Sugar beet genotypes significantly different in storage capacity especially carbohydrates (Schrepel and Hoffmann, 2013). According to Kenter et al., (2006), van Swaaij and Huijbregts (2010), in sugar beets geno-typic differences in storage losses exist which are enhanced with increasing storage duration (Kenter and Hoffmann, 2009).

Campbell and Klotz (2007) also found a significant genotype effect on storage losses, but it was rather low compared to the effect of the environment (growing site $\times$ year) and the inter-action (genotype $\times$ environment). The sugar beet genotype significantly affected sugar yield and storage besides root yield (Hoffmann et al ., 2005).

The study aims to evaluate three different sugar beet cultivars under three nitrogen fertilizer rates concerning root yield, root traits ,sucrose content and sucrose yield /ha under the arid land conditions.

\section{Materials and Methods}

This research was conducted during $2016 / 2017$ and 2017/2018 seasons in the Agricultural Research Station, King Abdulaziz University at Hada Al-Sham region, Saudi
Arabia. Three sugar beet (Beta vulgaris L.) Cultivars were tested under nitrogen fertilizer rates in a split plot design with 4 replications. The main plot treatments were 3 nitrogen fertilizer rates $(100,200$ and $300 \mathrm{~kg} \mathrm{~N} / \mathrm{ha}$ ). The sub plot treatments were 3 sugar beet cultivars: Farida polygerm cv. from Egypt, Dita monogerm cv. from Belgium and Heros polygerm cv. from Syria. The sub plot consisted of 10 rows with $3 \mathrm{~m}$ length, $4 \mathrm{~m}$ width and $40 \mathrm{~cm}$ between each 2 rows with 30 $\mathrm{cm}$ between hills. Surface drip irrigation system was used and the dripper lines was installed with $40 \mathrm{~cm}$ between two adjacent dripper lines while the distance between drippers is $30 \mathrm{~cm}$. The type of the dripper line is RAIN BIRD LD- 06- 12-1000 Landscape drip $0.6 \mathrm{G} / \mathrm{h} @ 12 "$. Inlet pressure on each tape was about 1.5 bars. The system uses 125micron disk filter. The common cultural practices other than the nitrogen fertilization were done according to El-Nakhlawy and Ghandorah , 2009. Root length, root weight and root yield/ha were measured at harvesting and sucrose content (\%) was determined using the Polarimetry method (A.O.A.C., 2006), also sucrose yield /ha was recorded from the data of sucrose (\%) and dry root yield $/$ ha.

\section{Statistical Analysis}

The obtained data of the experiment in the two seasons was statistically analyzed through analysis of variance procedures (ANOVA) then revised least significance difference (RLSD) test was used to compare between the treatment means after applying the statistical analysis assumptions according to ElNakhlawy (2010) using SAS (2006).

\section{Results and Discussions}

\subsection{Effect of Nitrogen Fertilizer Rates}

The statistical comparison between the means of the studied traits of sugar beet under the rates of nitrogen fertilizer (Tables 1 and 2) showed that the rate of $300 \mathrm{~kg} \mathrm{~N} / \mathrm{ha}$ produced 
the highest means in all traits. The results showed that as nitrogen rate increased sugar beet root length, diameter and weight significantly increased during the 2016/2017 and 2017/2018 seasons. Under $300 \mathrm{~kg} \mathrm{~N} / \mathrm{ha}$ root length increased by $105 \%$ and $126 \%$ compared to the $200 \mathrm{~kg} \mathrm{~N} / / \mathrm{ha}$ and $100 \mathrm{~kg} \mathrm{~N} / \mathrm{ha}$ in the first season, respectively, and with $102 \%$ and $108 \%$ in the second season. Root diameter increased by $108 \%$ and $115 \%$ in the first season and by $103 \%$ and $111 \%$ in the second season compared with $200 \mathrm{~kg} \mathrm{~N} / \mathrm{ha}$ and $100 \mathrm{~kg} \mathrm{~N} / \mathrm{ha}$ respectively. The positive response to increasing nitrogen rate was pronounced in root weight where it increased by $126 \%$ and $146 \%$ in the first season and by $114 \%$ and $52 \%$ in the second season compared with the 200 and $100 \mathrm{Kg} \mathrm{N} / \mathrm{ha}$. The Fresh root yield/ha under $300 \mathrm{~kg} \mathrm{~N} /$ ha was higher than under 200 and 100 $\mathrm{kg} \mathrm{N} / \mathrm{ha}$ by $114 \%$ and $127 \%$ as average of the 2 seasons. As for sucrose yield/ha, the obtained results showed that under $300 \mathrm{~kg} \mathrm{n} / \mathrm{ha}$ sucrose yields were $4.28 \mathrm{t}$ and $6.39 \mathrm{t} / \mathrm{ha}$ while under $100 \mathrm{~kg} \mathrm{~N} /$ ha were $2.7 \mathrm{t}$ and $3.93 \mathrm{t} / \mathrm{ha}$ in the first and second seasons, respectively (Table 2).

The linear response of sugar beet to nitrogen fertilizer rates might been due to the positive effect of increasing nitrogen rate on increasing leaf area and chlorophyll content of sugar plants, accordingly, it enhanced in increasing photosynthetic rate, accordingly increasing sugar beet root yield components, yield, sucrose content and sucrose yield/ha (Armstrong et al., 1986 and Malnou et al., 2006). The similar results were found by different authors where they reported that too little $\mathrm{N}$ retards leaf growth (Milford et al., 1985), gives pale green foliage due to low chlorophyll concentration and accelerates leaf senescence (Draycott and Christenson, 2003).

\subsection{Effect of Sugar Beet Cultivars}

The statistical comparisons of means of each root length, dimeter and weight of the three sugar beet cultivars during the 2 studied seasons (Table 3) showed that Farida cv had the tallest root in both seasons (228.6 and 215 $\mathrm{mm}$ ) with significant differences from Dita and Heros cv but no significant differences were found between Dita and Heros cvs in the 2 seasons.. Root lengths of the three cultivars were $(228.7 \mathrm{~mm}, 204.8 \mathrm{~mm}$, and $208.69 \mathrm{~mm})$ for Farida, Heros and Dita cvs, respectively (Table 3). Root diameter was higher in Farida $\mathrm{cv}$, and differed significantly from the other 2 cvs. In addition, significant differences were showed between Dida and Heros cvs in both seasons. Farida cv root diameter were 92,83 $\mathrm{mm}$ and $118.5 \mathrm{~mm}$ in the $1^{\text {st }}$ and $2^{\text {nd }}$ seasons, respectively followed by Dita cv $(88.15 \mathrm{~mm}$ and $115.6 \mathrm{~mm}$, respectively) then Heros with means of $70.72 \mathrm{~mm}$ and $113.42 \mathrm{~mm}$ in the $1^{\text {st }}$ and $2^{\text {nd }}$ season, respectively (Table 3 ). The statistical comparisons between the three sugar beet cultivars concerning root fresh weight (Table 3) showed significant differences between Farida cv and the other 2 cvs. Root fresh weight means were $804.37 \mathrm{~g}, 612.23 \mathrm{~g}$ and $602.823 \mathrm{~g}$ for Farida, Heros and Dita cvs, respectively in the first season. Farida cv produced the highest root yield /ha $(60.62 \mathrm{t} / \mathrm{ha})$ followed by Dita cv. (57.26 t/ha) then Heroes cultivar $45.62 \mathrm{t} / \mathrm{ha}$ ) in the first season. In addition, the same tred was found in the second season, while root yield/ha means were $97.00 \mathrm{t}, 90.72 \mathrm{t}$ and $64.55 \mathrm{t} / \mathrm{ha}$, respectively (Table 4). As fore, sucrose content (\%) in sugar beet root, Dita cv. Was the highest $(18.80 \%$ and $19.25 \%$ in the 2 seasons, respectively) followed by Farida (17.91\% and 18.335 , respectively) while Heros was the lowest sucrose (\%) with values of $11.80 \%$ and $13.26 \%$, respectively (Table 4). Sucrose yield/ha were similar in the trend as sucrose contents where Farida cv was the highest (4.15 $\mathrm{t}, 6.95 \mathrm{t}$ ) followed by Dita cv (3.43 t and 6.67 t) and the lowest was Heros cv (2.12 t and 3.35 $\mathrm{t} / \mathrm{ha}$ ) in the first and second seasons, respectively (Table 4). 
The obtained results showed that Farida cv. produced the highest sugar beet root yield and sucrose yield /ha, and these results might be due to the genetic makeup of Farida cv. and it had polygenes contributed in increasing yield components of root length, root diameter, root weight which reflected in increasing root yield /ha (Hoffmann et al., 2005). Increasing in yield components positively affected the sucrose biosynthesis within the root cells and produced the highest sucrose yield (Kenter et al., 2006 and Van Swaaij and Huijbregts, 2010).

\subsection{Effect of the Interaction between Nitrogen Fertilizer Rates and Sugar Beet Cultivars}

As for sugar beet root length, diameter and weight under the effect of the interaction between nitrogen fertilizer rates and cultivars, the presented data (Table 5) showed no significant differences were showed in the last three sugar beet traits in the two studied seasons.
The highest means of root length, dimeter and weight were produced from Farida cv. Under $300 \mathrm{~kg} \mathrm{~N} / \mathrm{ha}$ in the two seasons. In addition, the highest values from fresh root yield/ha, sucrose content (\%) and sucrose yield/ha were produced from Farida cv. Fertilized with $300 \mathrm{~kg} \mathrm{~N} / \mathrm{ha}$. Fresh root yield /ha ranged from 79.11t/ha to $40.69 \mathrm{t} / \mathrm{ha}$ in the first season and from 109.87 $\mathrm{t} /$ ha to $72.16 \mathrm{t} / \mathrm{ha}$ in the second season. Sucrose yield /ha ranged from $5.51 \mathrm{t} /$ ha to $1.69 \mathrm{t} / \mathrm{ha}$ in the first season and from $6.76 \mathrm{t}$ to $4.73 \mathrm{t} / \mathrm{ha}$ in the second season (Table 6).

The results of the interaction of the insignificance effects of the interaction on the six studied traits of sugar beet might been due to the same response of each genotype to the three nitrogen fertilizer rates for the physiological and metabolic traits, which reflected into the non-significance effects for the interaction (Campbell and Klotz, 2007).

Table 1. Means of root length $(\mathrm{mm})$, root diameter $(\mathrm{mm})$ and root fresh weight of sugar beet under the effect of nitrogen fertilizer rates during 2016/2017 and 2017/2018 seasons.

\begin{tabular}{|c|c|c|c|c|c|c|}
\hline \multirow{2}{*}{$\begin{array}{c}\text { Nitrogen } \\
\text { fertilizer rate } \\
(\mathbf{k g ~ N} / \mathbf{h a})\end{array}$} & \multicolumn{2}{|c|}{$\begin{array}{c}\text { Root length } \\
(\mathbf{m m})\end{array}$} & \multicolumn{2}{c|}{$\begin{array}{c}\text { Root diameter } \\
\mathbf{( m m})\end{array}$} & \multicolumn{2}{c|}{$\begin{array}{c}\text { Root fresh weight } \\
\mathbf{( g )}\end{array}$} \\
\cline { 2 - 7 } & $2016 / 17$ & $2017 / 18$ & $2016 / 17$ & $2017 / 18$ & $2016 / 17$ & $2017 / 18$ \\
\cline { 2 - 7 } & $194.22 \mathrm{c}^{*}$ & $196.16 \mathrm{c}$ & $77.57 \mathrm{c}$ & $110.22 \mathrm{c}$ & $536.23 \mathrm{c}$ & $643.89 \mathrm{c}$ \\
\hline 100 & $206.90 \mathrm{~b}$ & $208.55 \mathrm{~b}$ & $83.82 \mathrm{~b}$ & $119.41 \mathrm{~b}$ & $621.06 \mathrm{~b}$ & $857.6 \mathrm{~b}$ \\
\hline 200 & $217.72 \mathrm{a}$ & $212.76 \mathrm{a}$ & $89.01 \mathrm{a}$ & $122.60 \mathrm{a}$ & $783.44 \mathrm{a}$ & $979.03 \mathrm{a}$ \\
\hline 300 & &
\end{tabular}

*Means of each trait under the main factor treatments followed by the same letter are not significantly different according to RLSD at $\leq .0 .05$.

Table 2. Means of fresh root yield ( $t / h a)$, sucrose content $(\%)$ and sucrose yield/ha (t) of sugar beet under the effect of nitrogen fertilizer rates during $2016 / 2017$ and $2017 / 2018$ seasons.

\begin{tabular}{|c|c|c|c|c|c|c|}
\hline \multirow{2}{*}{$\begin{array}{c}\text { Nitrogen } \\
\text { fertilizer rate } \\
(\mathbf{k g} \text { N/ha) }\end{array}$} & \multicolumn{9}{|c|}{ Means } \\
\cline { 2 - 7 } & \multicolumn{2}{|c|}{$\begin{array}{c}\text { Fresh root yield/ha } \\
\text { (t) }\end{array}$} & \multicolumn{2}{c|}{$\begin{array}{c}\text { Sucrose content } \\
(\%)\end{array}$} & \multicolumn{2}{c|}{$\begin{array}{c}\text { Sucrose yield/ha } \\
\text { (t) }\end{array}$} \\
\cline { 2 - 7 } & $2016 / 17$ & $2017 / 18$ & $2016 / 17$ & $2017 / 18$ & $2016 / 17$ & $2017 / 18$ \\
\hline 100 & $58.53 \mathrm{c}^{*}$ & $80.05 \mathrm{c}$ & $15.31 \mathrm{c}$ & $15.81 \mathrm{c}$ & $2.7 \mathrm{c}$ & $3.93 \mathrm{c}$ \\
\hline 200 & $65.02 \mathrm{~b}$ & $90.80 \mathrm{~b}$. & $16.29 \mathrm{~b}$ & $17.01 \mathrm{~b}$ & $3.45 \mathrm{~b}$ & $5.06 \mathrm{~b}$ \\
\hline 300 & $74.09 \mathrm{a}$ & $101.42 \mathrm{a}$ & $17.02 \mathrm{a}$ & $17.96 \mathrm{a}$ & $4.28 \mathrm{a}$ & $6.39 \mathrm{a}$ \\
\hline
\end{tabular}

*Means of each trait under the main factor treatments followed by the same letter are not significantly different according to RLSD at $\leq .0 .05$. 
Table 3. Means of root length $(\mathrm{mm})$, root diameter $(\mathrm{mm})$ and root fresh weight of sugar beet cultivars during $2016 / 2017$ and $2017 / 2018$ seasons.

\begin{tabular}{|c|c|c|c|c|c|c|}
\hline \multirow{2}{*}{ Cultivars } & \multicolumn{4}{|c|}{ Means } \\
\cline { 2 - 7 } & \multicolumn{2}{|c|}{$\begin{array}{c}\text { Root length } \\
(\mathbf{m m})\end{array}$} & \multicolumn{2}{c|}{$\begin{array}{c}\text { Root diameter } \\
(\mathbf{m m})\end{array}$} & \multicolumn{2}{c|}{$\begin{array}{c}\text { Root fresh weight } \\
\mathbf{( g )}\end{array}$} \\
\cline { 2 - 7 } & $2016 / 17$ & $2017 / 18$ & $2016 / 17$ & $2017 / 18$ & $2016 / 17$ & $2017 / 18$ \\
\hline DITA & $208.69 \mathrm{~b}^{*}$ & $209.3 \mathrm{~b}$ & $88.15 \mathrm{~b}$ & $115.6 \mathrm{~b}$ & $602.8 \mathrm{~b}$ & $833.52 \mathrm{c}$ \\
\hline HEROS & $204.8 \mathrm{~b}$ & $210 \mathrm{~b}$ & $70.72 \mathrm{c}$ & $113.42 \mathrm{c}$ & $612.23 \mathrm{~b}$ & $868.49 \mathrm{~b}$ \\
\hline FARIDA & $228.7 \mathrm{a}$ & $215 \mathrm{a}$ & $92.83 \mathrm{a}$ & $118.5 \mathrm{a}$ & $804.37 \mathrm{a}$ & $899.87 \mathrm{a}$ \\
\hline
\end{tabular}

*Means of each trait under the main factor treatments followed by the same letter are not significantly different according to RLSD at $\leq .0 .05$.

Table 4. Means of fresh root yield (t/ha), sucrose content $(\%)$ and sucrose yield/ha (t) of sugar beet cultivars during 2016/2017 and 2017/2018 seasons.

\begin{tabular}{|c|c|c|c|c|c|c|}
\hline \multirow{2}{*}{ Cultivars } & \multicolumn{4}{|c|}{ Means } \\
\cline { 2 - 7 } & \multicolumn{2}{|c|}{$\begin{array}{c}\text { Fresh root yield/ha } \\
\text { (t) }\end{array}$} & \multicolumn{2}{c|}{$\begin{array}{c}\text { Sucrose content } \\
(\%)\end{array}$} & \multicolumn{2}{c|}{$\begin{array}{c}\text { Sucrose yield/ha } \\
\text { (t) }\end{array}$} \\
\cline { 2 - 7 } & $2016 / 17$ & $2017 / 18$ & $2016 / 17$ & $2017 / 18$ & $2016 / 17$ & $2017 / 18$ \\
\hline DITA & $57.26 \mathrm{~b}^{*}$ & $90.72 \mathrm{~b}$ & $18.80 \mathrm{a}$ & $19.25 \mathrm{a}$ & $3.43 \mathrm{~b}$ & $6.67 \mathrm{~b}$ \\
\hline HEROS & $45.62 \mathrm{c}$ & $64.55 \mathrm{c}$ & $11.80 \mathrm{~b}$ & $13.26 \mathrm{c}$ & $2.12 \mathrm{c}$ & $3.35 \mathrm{c}$ \\
\hline FARIDA & $60.62 \mathrm{a}$ & $97.00 \mathrm{a}$ & $17.91 \mathrm{a}$ & $18.33 \mathrm{~b}$ & $4.15 \mathrm{a}$ & $6.95 \mathrm{a}$ \\
\hline
\end{tabular}

*Means of each trait under the main factor treatments followed by the same letter are not significantly different according to RLSD at $\leq .0 .05$.

Table 5. Means of root length $(\mathrm{mm})$, root diameter $(\mathrm{mm})$ and root fresh weight $(\mathrm{g})$ under the effect of the interaction between nitrogen fertilizer rates and sugar beet cultivars during 2016/2017 and 2017/2018 seasons.

\begin{tabular}{|c|c|c|c|c|c|c|c|}
\hline \multirow{3}{*}{$\begin{array}{l}\text { Nitrogen } \\
\text { fertilizer } \\
\text { rate } \\
\text { (kg N/ha) }\end{array}$} & \multirow{3}{*}{ Cultivars } & \multicolumn{6}{|c|}{ Means } \\
\hline & & \multicolumn{2}{|c|}{$\begin{array}{l}\text { Root length } \\
\text { (mm) }\end{array}$} & \multicolumn{2}{|c|}{$\begin{array}{l}\text { Root diameter } \\
\qquad(\mathbf{m m})\end{array}$} & \multicolumn{2}{|c|}{$\begin{array}{c}\text { Root fresh weight } \\
\text { (g) }\end{array}$} \\
\hline & & $2016 / 17$ & $2017 / 18$ & $2016 / 17$ & $2016 / 17$ & $2017 / 18$ & $2016 / 17$ \\
\hline \multirow{3}{*}{100} & DITA & 185.95 & 194.06 & 68.8 & 101.4 & 487.48 & 597.02 \\
\hline & HEROS & 195.25 & 190.68 & 70.45 & 114.4 & 458.5 & 589.89 \\
\hline & FARIDA & 201.48 & 203.75 & 93.47 & 114.88 & 662.73 & 744.78 \\
\hline \multirow{3}{*}{200} & DITA & 207.93 & 208.21 & 76.22 & 114.1 & 545.92 & 896.31 \\
\hline & HEROS & 206.36 & 200.76 & 76.80 & 124.18 & 546.17 & 780.92 \\
\hline & FARIDA & 212.42 & 216.7 & 98.45 & 119.96 & 771.11 & 895.59 \\
\hline \multirow{3}{*}{300} & DITA & 218.18 & 214.7 & 75.33 & 129.3 & 775.01 & 1007.2 \\
\hline & HEROS & 212.87 & 204.75 & 84.87 & 117.7 & 596.04 & 870.66 \\
\hline & FARIDA & 222.13 & 218.83 & 106.85 & 120.82 & 979.28 & 1059.2 \\
\hline \multicolumn{2}{|c|}{ RLSD (0.05) } & NS & NS & NS & NS & NS & NS \\
\hline
\end{tabular}

NS: not significant at $\mathrm{p} \leq 0.05$. 
Table 6. Means of fresh root yield (t/ha), sucrose content $(\%)$ and sucrose yield/ha $(t)$ of sugar beet under the effect of the interaction between nitrogen fertilizer rates and sugar beet cultivars during 2016/2017 and 2017/2018 seasons.

\begin{tabular}{|c|c|c|c|c|c|c|c|}
\hline \multirow{3}{*}{$\begin{array}{c}\text { Nitrogen } \\
\text { fertilizer rate } \\
\text { (kg N/ha) }\end{array}$} & \multirow{3}{*}{ Cultivars } & \multicolumn{6}{|c|}{ Means } \\
\hline & & \multicolumn{2}{|c|}{$\begin{array}{l}\text { Fresh root yield } \\
(\mathrm{t} / \mathrm{ha})\end{array}$} & \multicolumn{2}{|c|}{ Sucrose content $(\%)$} & \multicolumn{2}{|c|}{ Sucrose yield/ha (t) } \\
\hline & & 2016/17 & 2017/18 & 2016/17 & 2016/17 & 2017/18 & 2016/17 \\
\hline \multirow{3}{*}{100} & DITA & 59.69 & 82.33 & 17.82 & 17.83 & 3.29 & 4.73 \\
\hline & HEROS & 40.82 & 72.16 & 10.95 & 12.3 & 1.69 & 2.31 \\
\hline & FARIDA & 62.09 & 85.68 & 17.16 & 17.29 & 3.37 & 4.74 \\
\hline \multirow{3}{*}{200} & DITA & 68.96 & 87.22 & 19.08 & 19.54 & 4.30 & 5.29 \\
\hline & HEROS & 42.22 & 89.78 & 11.86 & 13.2 & 2.13 & 3.06 \\
\hline & FARIDA & 69.42 & 95.51 & 17.94 & 18.47 & 3.93 & 6.84 \\
\hline \multirow{3}{*}{300} & DITA & 79.11 & 102.61 & 19.65 & 20.4 & 4.72 & 8.26 \\
\hline & HEROS & 51.82 & 91.8 & 12.77 & 14.26 & 2.61 & 4.17 \\
\hline & FARIDA & 78.36 & 109.87 & 18.65 & 19.24 & 5.51 & 6.76 \\
\hline \multicolumn{2}{|c|}{ RLSD (0.05) } & NS & NS & NS & NS & NS & NS \\
\hline
\end{tabular}

NS: not significant at $\mathrm{p} \leq 0.05$.

\section{Conclusion}

The obtained results of the present study showed that the $300 \mathrm{~kg} \mathrm{~N} / \mathrm{ha}$ produced the highest root traits, root yield/ha and sucrose content (\%) and sucrose yield/ha. Farida polygerm cv. was the highest $\mathrm{cv}$ in sugar beet root yield and yield components followed by Dita monogerm cv. and the lowest was Heros polygerm cv. also, Farida cv. was the highest in sucrose yield/ha followed by Dita $\mathrm{cv}$ but dita cv was the highest in sucrose content followed by Farida while the lowest cultivar in sucrose content and sucrose yield/ha was Heros cultivar.

\section{References}

A.O.A.C. (2000). Association of Official Agricultural Chemists. Official Methods of Analysis of the AOAC International, 17th, Ed. Washington, D.C., USA.

Armstrong, M. J., Milford, G. F. J., Pocock, T. O., Last,P. J. and Day, W. (1986). The dynamics of nitrogen uptake and its remobilization during the growth of sugar beet. Journal of Agricultural Science, Cambridge, 107: 145-154.

Campbell, L.G. and Klotz, K .L. (2007). Characterizing sugar beet varieties for post-harvest storage losses is complicated by environment effects and genotype $\mathrm{x}$ environment interactions. Can. J. Plant Sci., 87: 121-127.
Cooke, D.A. and Scott, R.K. (1993). "The Sugar Beet Crop". Chapman and Hall, London, pp. 262-265.

Draycott, A.P. and Christenson, D.R.( 2003). Nutrients for Sugar Beet Production: Soil-Plant Relationships. CAB International, Wallingford, $242 \mathrm{pp}$.

Dutton, J. and Huijbregts, T. (2006). Root quality and processing. In: Draycott, A.P. (Ed.), Sugar Beet. Blackwell Publishing, Oxford, pp. 409-442.

El-Nakhlawy, F. S. (2010). Statistical Design and Analysis in Scientific Research. Sci. Pub Center, King Abdulaziz University, Saudi Arabia.

Hills, F.J., Broadbent, F.E. and Lorenz, O.A. (1983). Fertilizer nitrogen utilization by corn, tomato, and sugar beet. Agron. J., 75:423-426.

Hoffmann, C.M., Kenter, C. and Bloch, C. (2005). Marc concentration of sugar beet (Beta vulgaris $\mathrm{L}$ ) in relation to sucrose storage. J. Sci Food Agric., 85: 459-465.

Jaggard K.W. and Qi, A. (2006). Crop physiology and agronomy. In: Draycott , A.P. (Ed.), Sugar Beet. Blackwell Publishing, Oxford, pp. 134-168.

Jaggard, K.W., Limb, M. and Proctor, G.H. (1995). Sugar Beet: A Grower's Guide. Sugar Beet Research and Education Committee, $111 \mathrm{pp}$.

Katerji, N., van Homm, J.W., Hamdy A., Mastrorilli, M. and Mou Karzel, E. (1997). Osmotic adjustment of sugar beets in response to soil salinity and is its influence on stomata conductance, growth and yield. Agricultural water Management, 34: 57-69. 
Kenter, C., Hoffmann, C. and Märländer, B. (2006): Sugar beet as raw material - Advanced storage management to gain good processing quality. Zuckerind., 131: 706-720.

Kenter, C. and Hoffmann C.M. (2009). Changes in the processing quality of sugar beet (Beta vulgaris L.) during long-term storage under controlled conditions. Int. J. Food Sci. Technol., 44: 910-917.

Malnou, C.S., Jaggard, K.W. and Sparkes, D.L. (2006). A canopy approach to nitrogen fertilizer recommendation for the sugar beet crop. Eur. J. Agron., 25: 254-263.

Milford, G.F.J., Pocock, T.O., Jaggard, K.W., Biscoe, P.V., Armstrong, M.J., Last, P.J. and Goodman, P.J. (1985). An analysis of leaf growth in sugar beet. 4.The expansion of the leaf canopy in relation to temperature and nitrogen. Ann. Appl. Biol., 107: 335-347.

Milford, G.F.J., Travis, K.Z., Pocock, T.O., Jaggard, K.W. and Day, W. (1988). Growth and dry matter partitioning in sugar beet. J. Agric. Sci., Camb., 110: $301-308$.
Refay, Y. A. (2010). Root yield and quality traits of three sugar beet (Beta vulgaris $\mathrm{L}$ varieties in relation to sowing date and stand densities. World J. Agric. Sci., 6 (5): 589-594.

Russell, E. W. (1971). Soil structure: its maintenance and improvement. Journal of Soil Science, 22: 137 - 151.

SAS Institute (2006). SAS users guide: Statistics. Version 8. SAS Inst., Cary, NC., USA.

Schrepel, K. and Hoffmann, C. (2013). Calculation of invert sugar content based on the glucose content of sugar beet. Sugar Industry/Zuckerind.,138: 463-470.

Scott, R.K., Jaggard, K.W. and Sylvester-Bradley, R. (1994). Resource capture by arable crops. In: Monteith, J.L., Scott, R.K. and Unsworth, M.H. (Eds.), Resource Capture by Crops. Nottingham University Press, pp. 279-302.

Van Swaaij, N. and Huijbreyts, T. (2010). Long-term storability of different sugar beet genotypes results of a joint IIRB study Sugar Industry, Zuckerindstrie, 135 (11): 661-667. 


\title{
استجابة أصناف مختلفة من بنجر السكر لمعدلات من السماد النبتزوجيني غسان حيدر إدريس، و فتحي سعد النخلاوي، و صالح محمود إسماعيل
}

\author{
قسم زراعة المناطق الجافة، كلبة الأرصاد والبيئة وزراعة المناطق الجافة، جامعة الملك عبد العزبز، جدة، \\ المملكة العربية السعودية \\ ghassanedrees983@gmail
}

المستخلص. أجريت هذه الدراسة بمحطة الأبحاث الزراعية التابعة لجامعة الملك عبد العزيز

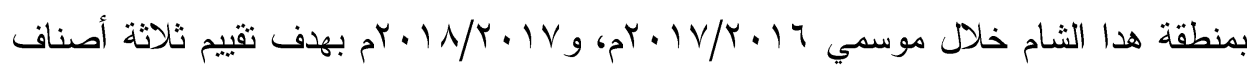
من بنجر السكر (فريدة، وديتا، وهيروس) تحت تأثثر ثلاثة مستويات من السماد النيتروجيني

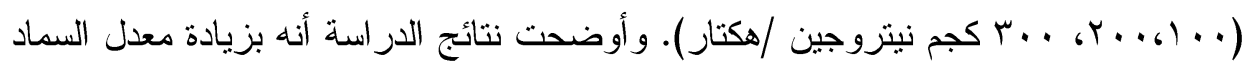

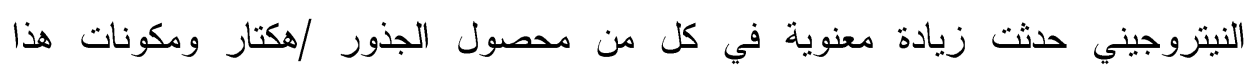
المحصول من طول الجذر وقطره ووزن الجذر، وأيضاً في نسبة السكروز بالجذور

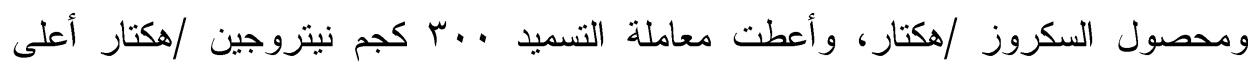
محصول جذور وسكر في الموسمين، وكان الصنف فريدة هو الأعلى في محصول الجذور

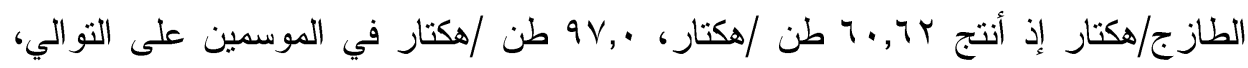

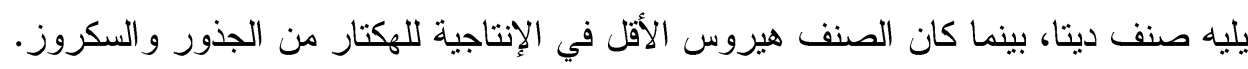
وقد أنتج الصنف فريدة أعلي محصول سكروز في الموسمين (10,؛ طن، 90, 7 طن/هكتار علي التو الي). الكلمات المفتاحية: أصناف، بنجر السكر، سكروز، سماد نيتروجيني، محصول الجذور. 